\title{
The Effect of Crude Extract of Pandanus conoideus Lamb. var. Yellow Fruit on Apoptotic Expression of the Breast Cancer Cell Line (T47D)
}

\author{
OKID PARAMA ASTIRIN", MARTI HARINI, NOOR SOESANTI HANDAJANI \\ Biology Department, Faculty of Mathematics and Natural Science, Sebelas Maret University, Surakarta 57126. \\ Received: $2^{\text {nd }}$ November 2008. Accepted: $16^{\text {th }}$ December 2008.
}

\begin{abstract}
A mechanism controlling a growing cancer cells is by a programmed cell death (apoptosis). The wildtype-p53 enable to stop cleaves that follow DNA repair or cell death (apoptosis). The mutation of wt-p53 caused loosing its ability to inhibit cancer cells proliferation. Healing methods like surgery, radiation, immunotherapy and chemotherapy still have some weaknesses, and clinical medicine to cancer is also still has any dissatisfactory. Much of chemotherapy was not given optimal result yet, because no specific action to cancer cells only, but also to the normal cells. These problems encourage important effort to find specific and sensitive anticancer. Empirical evidence indicates that the crude extract of Pandanus conoideus Lamb var. yellow fruit has potential effect as an anticancer. Method of Freshney was used in growing T47D cell line, counting cells was done by direct counting, and apoptotic evaluation was done by TUNEL enzymatic labeling assay. The results of the research demonstrated that the LC50 of yellow fruit extract are $0.25 \mu \mathrm{L} / \mathrm{mL}$. The percentage of apoptotic of $0.125 \mu \mathrm{L} / \mathrm{mL}$, $0.0625 \mu \mathrm{L} / \mathrm{mL}$, and $0.03125 \mu \mathrm{L} / \mathrm{mL}$ are $34.38 \pm 2.26,30.03 \pm 3.87$ and $21.07 \pm 1.14$ respectively.
\end{abstract}

(C) 2009 Biodiversitas, Journal of Biological Diversity

Key words: T47D, Apoptotic, p53, Pandanus conoideus Lamb. var. yellow fruit.

\section{INTRODUCTION}

There are more than 30 kinds of Pandanus sp. (Widiyanto, 2006). Fourteen taxon from Pandanaceae were classified into red fruit, and wellknown for its beneficial use, while the rest of them belong to the group of yellow fruit, namely awone mengkaki by local people of Serui. Pandanus conoideus Lamb. at present is known by local people in that area as the red fruit, and this plant endemically growing in Papua. Four varieties of $P$. conoideus are cultivated by peoples in that area because its economical value as medicinal plant. Those are $P$. conoideus var. long red fruit, short red fruit, brown fruit, and yellow fruit. The importance of those fruits as traditional medicine provide prominent source as of new anticancer agent originated from Indonesia. The red fruit plant at present undergo over-exploitation, and its population reduced drastically due to utilisation of its fruits by traditional medicine producers both from Indonesia and other country. Empirical experience shows that $P$. conoideus var. yellow fruit (later abbreviated as yellow fruit) could act as anticancer, however, the

- Corresponding address:

JI. Ir. Sutami 36A Surakarta 57126

Tel. \& Fax.: +62-271-663375

e-mail: parama_astirin@yahoo.com mechanism underlying the inhibition of cancer cell by this fruit is still not fully understood yet.

The yellow fruit has been analysed by I Made Budi the person who found the red fruit, it contain tocopherol and $\beta$-carotene higher than that of red fruit (personal communication, 2007). Natural subtances found in this fruit such as carotene $(9,500 \mathrm{ppm}), \beta$ carotene (240 ppm), tocopherol (10,400 ppm), and also oleic acid, linoleic acid and decanoic acid of omega 3 and omega 9 are known as powerfull antioxidant, aiding in preventing many deseases including cancer.

Breast cancer is the most common cause of death from cancer among women in the world. Mostly the victim of breast cancer (60-70\%) was because of too late in testing it, so that it causes their death (KlauberDeMore et al., 2001). It globally takes the second place of women death after cervic cancer. In Indonesia, victim of breast cancer gradually increases by year, whereas United State reports that 27 in $100.000(18 \%)$ of death are caused by breast cancer (Tjindarbumi and Mangunkusumo, 2002; Meiyanto et al., 2006).

The main problem of chemoterapi is in it's low selection in anti-cancer medicine (Valeriote et al., 2002; Kinghom et al., 2003; Jenie and Meiyanto 2007). The use of radiation for theraphy like chemotheraphy and hormonal therapy, could result in 
any other effects to human body such as hairfall, skin getting darker (Jiang et al., 2004). This problem has lead to promote the use of traditional medicine, which is generally believed to have less side effect (Sugiyanto et al., 2003). One of the strategy to find the compound that works as target of its action to several gene which regulate the growth or proliferation of the cells (Gibbs, 2000).

The T47D breast cancer cell line (from ATCC, American Tissue and Culture Collection) is cell taken from epitelium of mamae ductus cell suffering malignation. This cell has a gene mutation of $p 53$ in the positive of amino acid $194^{\text {th }}$, with the fenilalanin amino acid (M;194F) (Nigro et al., 1989). The mutation at the p53 gene often found following a non regulated genetic as long as carsinogenesis in mostly tumor kind, included the breast cancer and cancerderived cell lines (Smardova et al., 2005). In this cells p53 mutation occurred at the 194 residue (in the zinc binding domain L2), so that $p 53$ loose its function. If the $p 53$ is not link with DNA, so that the potential of regulating cell cycle and apoptosis could be reduce or completely lost (Schafer et al., 2000).

The main principle of the effectivity and potential selection of anti cancer could be dealed with mutated p53, so that the apoptosis of cancer cells could proceeded. In general, the objective of the reseach were to promote the use of the variety of plantation in Indonesia, by using the yellow fruit especially as an agent which is cytotoxic, and provide scientific reasons of the use of the yellow fruit as a cancer medicine in society. The research on the cytotoxicity effect of yellow fruit extract toward cell line of cancer T47D should be investigated by observing the effect of cytotoxicity in inhibition mechanism of the cell growth (cycle of the cell) and apoptosis especially in relation with the expression of the $p 53$ gene.

\section{MATERIALS AND METHODS}

The T47D growth was monitored according to the method described elsewhere (Freshney, 2000). The cells linkage was counted using $20 \mu \mathrm{L}$ of cell suspesion, added with $180 \mu \mathrm{L}$ of tryphan blue, and the cells was then counted with haemocytometer at the fase contrast microscope. The total of cells found then multiplied with liquidity factor and number $10^{4} / \mathrm{mL}$ (Freshney, 1987). The extract of the yellow fruit was taken from fresh yellow fruit. Solution of the test made by dissolving DMSO (dimethyl sulfoxide) $0.25 \%$ filtered with microfilter with diameter of $0.22 \mu \mathrm{m}$ until the suspencion is in homogenious condition and then put in a sterile cup as main solution. Cytotoxicity test was done by pouring in $100 \mu \mathrm{L}$ complete medium consist of cell suspension with closeness around $2 \times 10^{5}$ cells $/ \mathrm{mL}$ into each well 96 hole micro culture.

The effect of inhibited kinetic proliferation after treatment with yellow fruit toward cell T47D, inhibition test of proliferation kinetics was done for $\mathbf{7 2}$ hours, by counting the growth of cells $(12,24,48,72)$.
Apoptosis observation was done with TUNEL enzymatic labelling assay. Cell suspension was dropped to the slides and was incubated in poly- $\mathrm{L}$ lysine, fixed with $4 \%$ formaldehide in the PBS prior to permeabilization by Triton $\mathrm{X}-100$. This step was followed by washing and rewashing using PBS. DNA was labelled with fluorescence-12-dUTP after TdT enzyme treatment. Slides were then covered with plastic coverslip and incubated at $37^{\circ} \mathrm{C}$ for 1 hour, by avoiding direct exposure to sunlight/roomlight. To stop the reaction, coverslip was removed and SSC (Sodium Saline Citrate) was added for $2 \times 5$ minutes. Slide were washed with PBS before addition of propidium iodine, then rewashed with PBS. Sample were analized under fluorescence microscope. The apoptotic cell will appear in green, while nonapoptotic in red. The treatment to control the positive TUNEL was done by adding DNA-ase I enzyme after permeabilization with TritonX-100 and beeing washed with PBS.

\section{RESULTS AND DISCUSSION}

The results given in Table 1 . shows that the extract of yellow fruit inhibits the growth/proliferation of T47D cell. This experiment was performed to know the cytotoxicity potential of the yellow fruit extract toward T47D cell with parameter of $\mathrm{LC}_{50}$ percentage of T47D cell.

Table 1. The percentage of T47D cell death after treatment with the crude extract of $P$. conoideus var. yellow fruit

\begin{tabular}{|c|c|c|c|c|}
\hline Concentration & The & rcenta & of death & Mean +SD \\
\hline$(\mathrm{L} / \mathrm{L})$ & I & II & III & IVIean \\
\hline Control & 0 & 0 & 0 & $0 \pm 0$ \\
\hline 4 & 100 & 100 & 100 & $100 \pm 0$ \\
\hline 2 & 92.68 & 95 & 92.68 & $93.45 \pm 1.34$ \\
\hline 1 & 72.09 & 68.18 & 70.45 & $70.24 \pm 1.96$ \\
\hline 0.5 & 59.57 & 58.33 & 59.57 & $59.16 \pm 0.72$ \\
\hline 0.25 & 50 & 50 & 50 & $50 \pm 0$ \\
\hline 0.125 & 40.38 & 39.62 & 48.83 & $42.94 \pm 5.11$ \\
\hline 0.0625 & 32.14 & 31.58 & 31.58 & $31.77 \pm 0.32$ \\
\hline 0.03125 & 26.66 & 26.23 & 26.23 & $26.37 \pm 0.25$ \\
\hline 0.0015625 & 20.63 & 19.05 & 19.05 & $19.58 \pm 0.91$ \\
\hline 0.0078125 & 13.64 & 13.64 & 13.43 & $13.57 \pm 0.12$ \\
\hline 0.00390625 & 5.7 & 7.04 & 5.7 & $6.15 \pm 0.77$ \\
\hline
\end{tabular}

$\mathrm{LC}_{50}$ of yellow fruit toward T47D cell after 24 hours incubation is $0.25 \mu \mathrm{L} / \mathrm{mL}$. According to Ueda et al. (2002) the extract of plantation with $\mathrm{LC}_{50}<100 \mathrm{~g} / \mathrm{mL}$ is potential to be developed as anti cancer. In this experiment, DMSO was used as solvent despite of water since the extracted compound was difficult to dissolve in water. Nogaki et al. (1998) reported that DMSO does not disturbing the growth of HL-60 cell and HSC-40, so that it can be used as solvent. We assumed that $0.7 \%$ DMSO used in this experiment will not significantly influence percentage of life and morphology of T47D cell.

Based on Figure 1. Significant effect of the yellow fruit extract on T47D death cell was observed. 
Correlation between extract concentration and the level of of expression of p53 mutant is shown with $r$ value of 0.967 . This figure shows that the extract concentration under $\mathrm{LC}_{50}$ inhibited the level of expression of $p 53$ significantly. This possibly caused by the excistance of the bioactive compound (tocopherol, $\beta$-carotene and carotene) in the extract which inhibit proliferation of T47D cells. Research by Carlisle et al. (2000) found that tocopherol could induce apoptosis and promote the expression of p53 in the lung cancer (HLF cell). Moreover, the combination of tocopherol and vitamine A shown that it could inhibit the growth of metastasis in breast cancer cell in transgenic experiment (Albright et al., 2004). The activition of the p53-wildtype might happen due to the reactivation of $p 53$ mutant. Beside this, there is also possibility that the reactivation of biological function of p53-wtp which was done by some compound in the yellow fruit.

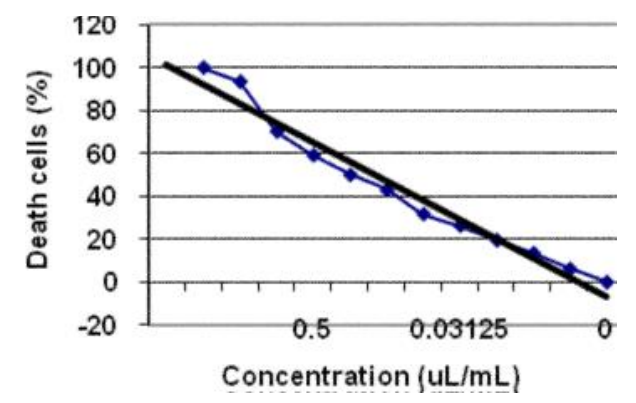

Figure 1. The effect of the crude extract of $P$. conoideus var. yellow fruit on death of T47D cell.

In general, the treatment with yellow fruit extract could significantly inhibit the growth of T47D cell as indicated by doubling time test (Table 2). Addition extract of yellow fruit with dosis of $0.125 \mathrm{uL} / \mathrm{mL}$ made a reaction the doubling time from 20.362 hours become 37.989 hours (1.86 time), while at the concentration of $0.0625 \mu \mathrm{L} / \mathrm{mL}$ and $0.03125 \mu \mathrm{L} / \mathrm{mL}$ its reaction time longer and the value of doubling time become 27.376 hours (1.34 times) and 23.220 hours (1.14 times).

Table 2. The regression similarity between number of cells in certain incubation time and the doubling time.

\begin{tabular}{lcccccc}
\hline Material & $\begin{array}{c}\text { Concen- } \\
\text { tration } \\
(\mu \mathrm{L} / \mathrm{mL})\end{array}$ & $\begin{array}{c}\text { The line equation } \\
\text { of the incubation } \\
\text { time versus the } \\
\text { amount of cells }\end{array}$ & $\begin{array}{l}\text { Slope } \\
\text { value }\end{array}$ & $\mathrm{R}^{2}$ & $\begin{array}{c}\text { Doubling } \\
\text { time } \\
\text { value }\end{array}$ \\
\hline Crude extract of Control & $\begin{array}{l}\mathrm{Y}=0.1988 \mathrm{X}+0.562 \\
0.1988\end{array}$ & 0.923 & 20.322 \\
P. conoideus & 0.03125 & $\mathrm{Y}=0.159 \mathrm{X}+0.91$ & 0.159 & 0.929 & 23.220 \\
var. yellow fruit & 0.0625 & $\mathrm{Y}=0.125 \mathrm{X}+1.18$ & 0.125 & 0.944 & 27.376 \\
& 0.125 & $\mathrm{Y}=0.088 \mathrm{X}+1.259$ & 0.088 & $\mathbf{0 . 8 9 9}$ & 37.989 \\
\hline
\end{tabular}

The discovery of the compound potential as cytostatic agent for p53 is very important in the effort of healing cancer. This is due to the cell cancer in human being is usually caused by abnormal function of the p53, so that the growth of cancer could be inhibitted by applying such compound.

Based on the promoting effect of cytostatic due to the addition of yellow fruit extract, there is a possibility of activating p53-wildtype so that it will be the process of apoptosis. Nuclear fragmentation as marker of apoptosis in a microscopic scale show increased in the treatment of the extract in the concentration close to the $\mathrm{LC}_{50}$.

Apoptotic test to know the effect of the yellow fruit extract in inducing apoptosis in T47D cells wad carried out by TUNEL enzymatic assay staining, and observed under the fluorescens microscope. The positive apoptosis cells will be in bright green color, whereas the viable cells will be in orange color (Rode et al., 2004). Both viable cells and apoptotic cells are presented in Figure 2. TUNEL is a quick method to identify and know the cells quantity which getting apoptosis in cell culture treatment (Wyllie, 2000; Wieder, 2005; Darzynkiewicz et al., 2008).

Decreasing amount of viable cells after treated by yellow fruit extract indicated the blocking of cell proliferation that occurs related to the decreasing of protein synthesis as needed in the process of proliferation. The TUNEL enzymatic assay staining was employed to evaluate morphological change of T47D. The cells that undergo apoptosis appear as green colour, while the cells that experiencing the first apoptosis, their plasma membrane is still intact and will be in orange colour, but begin to form the chromatin condensation that resulting in green spots. It thus can be diferentiated between viable and necrotic cells. The percentage of apoptosis of T47D cells after 24 hours incubation with yellow fruit extract is presented in Table 3.

Table 3. The average percentage of apoptosis of T47D cells after 24 hours incubation with crude extract of $P$. conoideus var. yellow fruit.

\begin{tabular}{lc}
\hline Concentration $(\mathrm{L} / \mathrm{mL})$ & Apoptosis $(\% \pm \mathrm{SD})$ \\
\hline 0.125 & $34.38 \pm 2.26$ \\
0.0625 & $30.03 \pm 3.87$ \\
0.03125 & $21.07 \pm 1.14$ \\
\hline
\end{tabular}

The death cells include (i) apoptosis,the progammed cells death that physiologically to balance and it is marked by DNA fragmentation, chromatin condensation, decreasing the cells size, cytoplasmic prominent and forming apoptosis body (ii) necrosis, death cells pathologically bringing of inflamation (King, 2000).

The p53 protein code by $p 53$ gene is located in short arm of $17^{\text {st }}$ human chromosom. Two types of p53 protein is recognized i.e $p 53$ protein wild type and mutant type. The amount of $p 53$ protein wild type in nucleus is in small amount, labile and has short half life time so it could not be detected by immunohistochemical staining technique. This protein 

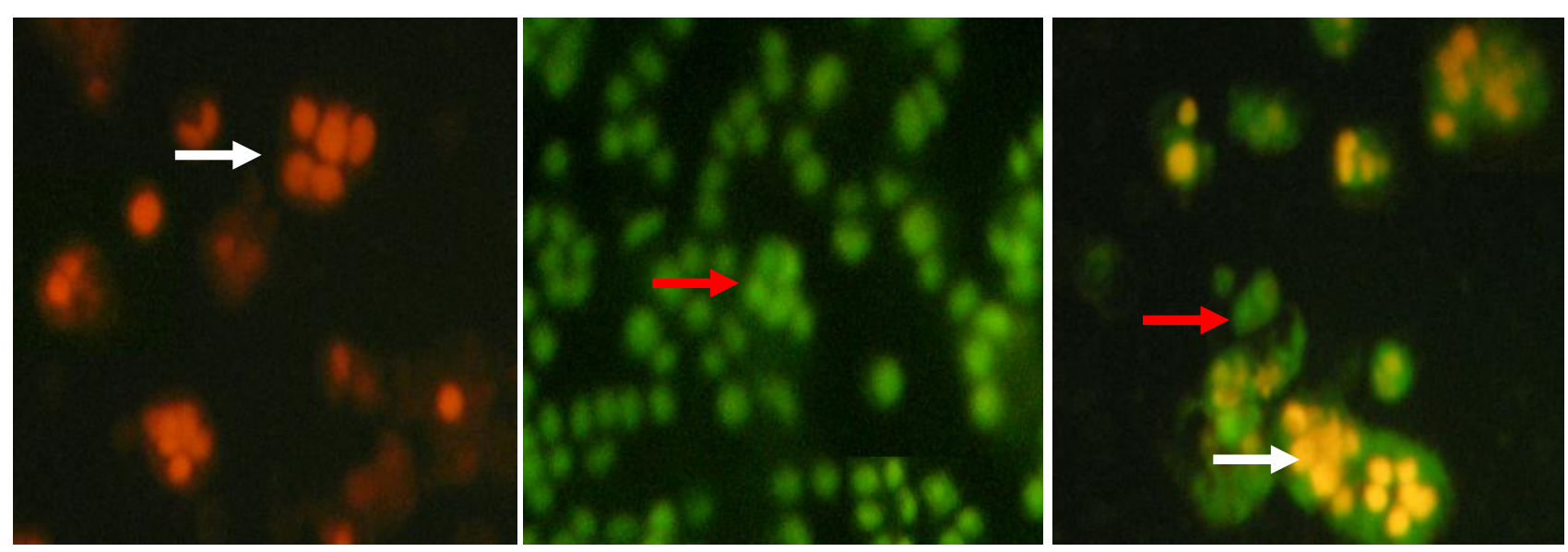

Figure 2. T47D cells after the treatment of crude extract of $P$. conoideus var. yellow fruit stained by TUNEL enzymatic assay. A. Negative control, B. Positive control of T47D cells undergo apoptotic (red arrow), C. Viable T47D cell (white arrow).

contribute to block cells proliferation, transcription, DNA repair and apoptosis, whereas p53 protein mutant type contribute in blocking the $p 53$ protein wild type until cells proliferation loss its resistance (Brock, 1993).

Controling cell cycle is done in order to perform a normal cycle. Cdk (cyclin dependent kinase) like Cdk 4 Cdk 6, Cdk 2 along with cyclin (cyclin D, cyclin E, cyclin A and cyclin B) are main substances involved in cells cycle, which bringing on the movement from G1 to $S$ or from G2 to M (Guardavoccaro et al., 2000). MPF (Maturation Promoting Factor) along with Cdk and cycling become progressively trigger the cell cycle. The p53 protein function as blocking of cell cycle if DNA damage taken place, and if a serious damage occurs could resulted in an apoptosis (Brown and Wouters, 1999).

\section{CONCLUSION}

The crude extract of Pandanus conoideus Lamb. var. yellow fruit is potential as anti cancer. The results of the research evidence that the $\mathrm{LC}_{50}$ of yellow fruit extract are $0.25 \mu \mathrm{L} / \mathrm{mL}$. The percentage of apoptotic in the dosage of $0.125 \mu \mathrm{L} / \mathrm{mL}, 0.0625 \mu \mathrm{L} / \mathrm{mL}$ and $0.03125 \mu \mathrm{L} / \mathrm{mL}$ are $34.38 \pm 2.26,30.03 \pm 3.87$ and $21.07 \pm 1.14$ respectively.

\section{REFERENCE}

Albright, C.D., R.I., Salganik, and T.V., Dyke. 2004. Dietary depletion of vitamin $\mathrm{E}$ and vitamin $\mathrm{A}$ inhibits mammary tumor growth and metastasis in transgenic mice. Journal of Nutrition 134: $1139-1144$.

Brock D.H.J. 1993. Molecular Genetic for the Clinician Chambridge: University Press.

Brown J.M and B.G. Wounter, 1999. Apoptosis $p 53$ and cancer cell sensitivity to anticancer agent. Cancer Research 59: 1391-99
Carlisle, D. L., D.E. Pritchard, J. Singh, and B.M. Owens. 2000. Apoptosis and p53 induction in human lung fibroblast exposed to chromium (VI): effect of ascorbate and tocopherol. Toxicological Science 55: 55-68

Darzynkiewicz, Z., D. Galkowski, and H. Zhao. 2008. Analysis of apoptosis by cytometry using TUNEL assay. Methods 44 (3): 250-254.

Freshney, R. 1987. Culture of animal Cells: A Manual of Basic Technique. New York: Alan R. Liss Inc.

Freshney, R. 2000. Culture of Animal Cells: A Manual of Basic Techniques. $4^{\text {th }}$ ed. New York: Wiley-Lies Publishing.

Gibbs, J.B. 2000. Mechanism-based target identification and drug discovery in cancer research. Science 287: 1970.

Guardavoccaro, D., G. Corente, F. Covone, L. Micheli, D'aguanol, G. Starase, M. Caruso, and F. Tisone. 2000. Arrest of G1-S progression by the $p 53$ inducible gene $p 53$ in Rb independent and relies on the inhibition of cyclin D1 transcription. Molecular and Cellular Biology 20: 1797-1815.

Jenie, R.I., dan E. Meiyanto, 2007. Ko-kemoterapi ekstrak etanolik daun sambung nyawa (Gynura procumbens (Lour.) Merr.) dan Doxorubicin pada sel kanker payudara. Majalah Farmasi Indonesia 18 (2): 81-87.

Jiang, Q., S. Christen, M.K. Shienaga, and B.N. Ames. 2004. YTocopherol or combinations of vitamin $E$ forms induce cell death in human prostate cancer cells by interrupting sphingolipid synthesis. PNAS 101 (51): 17825-17830.

King R.J.B., 2000. Cancer Biology. $2^{\text {nd }}$ ed. London: Pearson Education Lim.

Kinghorn, A.D., R.N. Farnsworth, D.D. Soejarto, and G.A. Cordell. 2003. Novel strategies for the discovery of plant-derived anticancer agents. Pharmaceutical Biology 41: 53-67.

Klauber-DeMore, N., K.J.V. Zee,. I. Linkov, P.I. Borgen, and W.L. Gerald. 2001. Biological behavior of human breast cancer micrometastases, Clinical Cancer Research 7: 2434-2439.

Meiyanto, E., Supardjan., M. Da'i, dan D. Agustina. 2006. Efek antiproliferatif pentagamavunon-0 terhadap sel kanker payudara T47D. Jurnal Kedokteran Yarsi 14 (1): 11-15.

Nogaki, A., K. Satoh, K. Iwasaka, H. Takano, M. Takahama, Y. Ida, and H. Sakagami. 1998. Radical intensity and cytotoxic activity of curcumin and gallic acid. Anticancer Research 18 (5A): 3487-3491.

Nigro, C.M., S.J. Baker, A.C Preisinger, J.M. Jessup, and R. Hoster. 1989. Mutation on the p53 gene occurring in drivers human tumor type. Nature 342: 705-708.

Rode, H.D., D. Eisel, and I. Frost. 2004. Apoptosis, Cell Death and Cell Proliferaton Manual. $3^{\text {rd }}$ ed. London: Roche Applied Science

Schafer, J.M., E.S. Lee, R.M O'Regan, K. Yao,and V.C. Jordan. 2000. Rapid development of tamoxifen-stimulated mutant $p 53$ 
breast tumors (T47D) in athymic mice. Clinical Cancer Research 6: 4373-4380.

Smardova, J., Sharkaphaviova., S. Miluska, and G. Diana. 2005 Analysis of $p 53$ status in human cell line using a functional assay in yeast : detection of new no sense p53 mutation in codon 124. Oncology Report 14: 901-907.

Sugiyanto, B., Sudarto, M. Edy, dan E.N. Agung, 2003. Aktivitas anti karsinogenik senyawa yang berasal dari tumbuhan. Majalah Farmasi Indonesia 14 (3): 132-141.

Tjindarbumi, D. and R. Mangunkusumo. 2002. Cancer in Indonesia, present and future, Journal of Clinical Oncology 32 (Supplement 1): S17-S2

Ueda, Y, Y. Tezuka, A.H. Banskota, Q.L Tran, Q.K. Tran, Y Harimaya, I. Saiki, and S. Kadota, 2002. Antiproliferatif activity of Vietnamese medicinal plants. Biology \& Pharmacology Bulletin 25 (6): 753-760

Valeriote F, C.K Grieshaber, J. Media, H. Pietraszkewics, J. Hoffmann, M. Pan, and S. Mc Laughlin. 2002. Discovery and development of anticancer agents from plants. Journal of Experimental Therapeutics and Oncology 2: 228-236

Widiyanto U., 2006. Ekspedisi ke kerajaan pandan. Majalah Tempo Edisi 42/XXXV/11-17 Desember 2006.

Wieder, R. 2005. TUNEL assay as a measure of chemotherapyinduced apoptosis. Methods on Molecular Medicine 111: 43-54.

Wyllie A., V. Donahue, B. Fischer, D. Hill, J. Keesey, and S. Manzow. 2000. Apoptosis and Cell Proliferation. 2nd revised ed. Mannheim, Germany: Boehringer Mannheim Biochemical. 